\title{
A Localized Decline in the Western Chorus Frog, Pseudacris triseriata, in Eastern Ontario
}

\author{
David C. Seburn ${ }^{1}$, CAROlyn N. L. Seburn $^{2}$, and Wayne F. Weller ${ }^{3}$ \\ ${ }^{1}$ Seburn Ecological Services, 2710 Clarenda Street, Ottawa, Ontario K2B 7S5 Canada; e-mail: davidseburn@ sympatico.ca \\ ${ }^{2} 2710$ Clarenda Street, Ottawa, Ontario K2B 7S5 Canada \\ 37038 Kelly Drive, Niagara Falls, Ontario L2H 3J9 Canada
}

Seburn, David C., Carolyn N. L. Seburn, and Wayne F. Weller. 2008. A localized decline in the Western Chorus Frog, Pseudacris triseriata, in eastern Ontario. Canadian Field-Naturalist 122(2): 158-161.

\begin{abstract}
To assess whether Western Chorus Frogs have declined in eastern Ontario, we conducted amphibian call surveys at 18 sites in the Cornwall area, where they were heard calling in 1990, as well as selected wetlands in the same area. Chorus frogs were detected at only 1 of the 18 original locations during surveys in 2001 and 2007. When survey locations with and without Chorus Frogs were considered, the site occupancy rate declined from 58\% in 1990, to only 12\% in 2007. Chorus Frogs appear to have declined in this area of eastern Ontario which is adjacent to documented declines in western Québec and northern New York.
\end{abstract}

Key Words: Western Chorus Frog, Pseudacris triseriata, Boreal Chorus Frog, Pseudacris maculata, amphibian decline, Ontario.

The Western Chorus Frog (Pseudacris triseriata) is a small hylid frog that occurs in the northcentral USA, southern Ontario and southwestern Québec (Conant and Collins 1998). An analysis of mitochondrial DNA has suggested that chorus frogs from eastern Ontario, adjacent Québec and northern New York should be assigned to the Boreal Chorus Frog ( $P$. maculata), rather than the Western Chorus Frog (Lemmon et al. 2007). The presence of more than one mitochondrial lineage within an amphibian species is not uncommon (e.g., Austin et. al. 2002). Therefore, the conclusion that eastern Ontario chorus frogs should be assigned to pure $P$. maculata may be premature.

A number of declines have been reported in the Western Chorus Frog. It was once considered common southeast of Montreal (Bleakney 1959), but now appears completely absent from the area (Daigle 1997) and is now extremely rare in Québec (Desroches and Rodrigue 2004). The Canadian and American Marsh Monitoring Program of the Great Lakes basin reported that the Western Chorus Frog was the only amphibian to decline significantly between 1995 and 1999 (Weeber and Vallianatos 2000) and it was one of four amphibian species to decline significantly from 1995 to 2004 (Crewe et al. 2006). A significant decline also occurred in northern New York (Gibbs et al. 2005). The Great Lakes/St. Lawrence - Canadian Shield population of Canada was designated threatened in April 2008 by the Committee on the Status of Endangered Wildlife in Canada, largely as a result of declines in Québec (COSEWIC 2008*).

To assess whether the Western Chorus Frog has declined in eastern Ontario, an area close to known declines in Québec and New York, we re-surveyed an area near Cornwall where it had been heard calling by one of us (WFW) at 18 of 31 survey locations on the evening of 30 April 1990 (Oldham and Weller 2000*). A potential flaw in follow-up surveys is only surveying the locations where a species was detected in the past. By surveying only historic locations, the only kind of change that can be detected is a decline. The regular extinction and colonization of amphibian species at particular wetlands is not uncommon (e.g. Hecnar and M'Closkey 1996) so follow-up surveys are likely to detect some localized extinctions. To compensate for this, two kinds of surveys were conducted: (1) Follow-up surveys: auditory monitoring at all locations where chorus frogs were detected in 1990, and (2) Site occupancy surveys: auditory monitoring at other appropriate habitats within the study area. By combining both kinds of surveys it would be possible to detect a decline or an increase in the percentage sites with chorus frogs.

\section{Study Area and Methods}

The chorus frog sites were located in Stormont, Dundas and Glengarry County (Figure 1, Table 1). Surveys in 1990 ranged from Cardinal to Cornwall. Western Chorus Frogs were detected only north of Long Sault, so 10 auditory stations to the southwest of Long Sault (Cardinal to Morrisburg) were excluded from all analyses. Western Chorus Frogs were heard at 18 of 31 auditory stations surveyed 30 April from approximately 20:00 to 23:00 h. Stations were selected by driving slowly with all car windows rolled down and stopping for 1-2 minutes at all locations where any calling frogs were heard.

Auditory follow-up surveys of 1-2 minutes were undertaken at 17 of the 18 Western Chorus Frog locations on the evening of 23-24 April 2001 from approxi- 


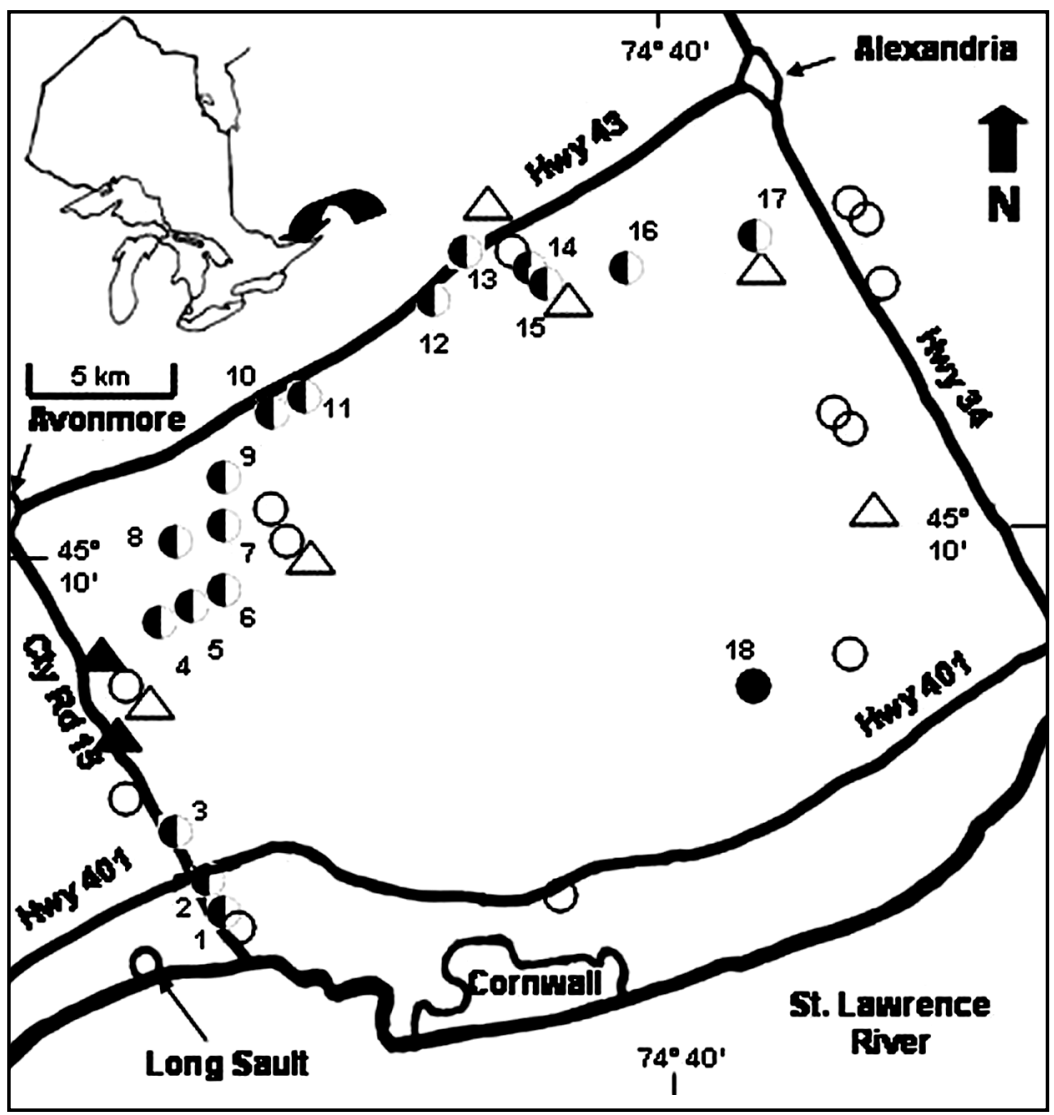

FIGURE 1. Survey locations for Western Chorus Frogs in eastern Ontario. Inset upper left is an outline of province of Ontario with arrow indicating study location. Circles represent original survey locations from 1990; solid: Chorus Frogs heard in 1990 and 2007; halffilled: Chorus Frogs heard in 1990, but not in 2001 or 2007; open: Chorus Frogs not heard in 1990. Triangles represent additional 2007 locations; solid: Chorus Frogs heard; open: Chorus Frogs not heard).

mately 20:00 to $01: 30 \mathrm{~h}$. A wetland with Western Chorus Frogs in Leeds and Grenville County was checked at the beginning and end of the survey to ensure Western Chorus Frogs were calling throughout the evening. The survey was repeated at all 18 chorus frog locations during the day on 20 April 2007, from approximately 10:00-18:00 h. The day was sunny with an air temperature above $10^{\circ} \mathrm{C}$. A wetland with Western Chorus Frogs in Ottawa was checked before the survey to ensure chorus frogs were calling that day. Site occupancy surveys were also conducted in 2007 at an additional 8 wetlands along the survey route that were visible from the road (Figure 1).

\section{Results}

Follow up surveys

Western Chorus Frogs were heard calling at none of 17 of 18 original chorus frog locations surveyed in
2001 and only 1 of the 18 locations surveyed in 2007 (Figure 1, Table 2). The one location where Western Chorus Frogs were heard in 2007 was not surveyed in 2001.

\section{Site occupancy surveys}

Western Chorus Frogs were heard calling in 2007 at 2 of 8 additional wetlands surveyed (Figure 1). Both locations were north of site 3 along County Road 15 and approximately $2 \mathrm{~km}$ apart $\left(45.0802^{\circ} \mathrm{N}\right.$, $7474.8954^{\circ} \mathrm{W}$ and $45.0966^{\circ} \mathrm{N}, 74.9087^{\circ} \mathrm{W}$ ). Overall, Western Chorus Frogs were detected at $58 \%$ of the 31 survey locations in this area in 1990, but only $12 \%$ of 26 locations in 2007.

\section{Discussion}

All sites with Western Chorus Frogs in 1990 were still present in 2001 and 2007, yet the species detected each year differed considerably (Table 2 ). The pres- 
TABLE 1. Locations in Stormont, Dundas and Glengarry County where Western Chorus Frogs were heard calling on 30 April 1990, 20:00-23:00 h.

\begin{tabular}{lccl}
\hline \hline Site & $\begin{array}{c}\text { Latitude } \\
\left({ }^{\circ} \mathrm{N}\right)\end{array}$ & $\begin{array}{c}\text { Longitude } \\
\left({ }^{\circ} \mathrm{W}\right)\end{array}$ & \multicolumn{1}{c}{ Location } \\
\hline 1 & 45.0438 & 74.8663 & County Road 15 \\
2 & 45.0555 & 74.8751 & County Road 15 \\
3 & 45.0672 & 74.8815 & County Road 15 \\
4 & 45.1059 & 74.8928 & $8^{\text {th }}$ Concession \\
5 & 45.1123 & 74.8699 & $8^{\text {th }}$ Concession \\
6 & 45.1167 & 74.8623 & $8^{\text {th }}$ Concession \\
7 & 45.1572 & 74.8609 & Quail Road \\
8 & 45.1491 & 74.8800 & Quail Road \\
9 & 45.1815 & 74.8736 & Highway 138 \\
10 & 45.2022 & 74.8595 & County Road 43 \\
11 & 45.2121 & 74.8379 & County Road 43 \\
12 & 45.2471 & 74.7715 & County Road 43 \\
13 & 45.2569 & 74.7562 & County Road 43 \\
14 & 45.2470 & 74.7346 & Loch Gary Road \\
15 & 45.2434 & 74.7333 & Loch Gary Road \\
16 & 45.2379 & 74.6964 & Kenyon Road \\
17 & 45.2701 & 74.6388 & Kenyon Road \\
18 & 45.0973 & 74.6399 & Glen Road \\
\hline \hline
\end{tabular}

ence of Gray Treefrogs (Hyla versicolor), the greater percentage of sites with American Toads (Anaxyrus americanus) and the lack of sites with Wood Frogs (Lithobates sylvaticus) in 1990 suggests that this survey took place relatively late in the anuran breeding season compared with the 2001 survey. Wood Frogs in particular are early breeders while Gray Treefrogs call relatively late in the spring breeding season. There were few sites with calling frogs in 2007 because the survey occurred during the day, when few species other than Western Chorus Frogs are consistently calling in eastern Ontario.

While it is possible that Western Chorus Frogs were still present at many of the Cornwall area sites but not calling during the follow-up surveys, this is unlikely for three reasons. First, we conducted two follow-up surveys, increasing the probability that Western Chorus Frogs would be detected if present. Second, surveys were conducted at optimal times, as Western Chorus Frogs were calling at known sites during both followup surveys. Third, when one of us (DCS) re-surveyed historic locations from the Ontario Herpetofaunal Atlas database (Oldham and Weller 2000*) in rural west Ottawa when Western Chorus Frogs were known to be calling in 2007 and 2008, chorus frogs were detected at over $60 \%$ of the historic locations after just a single visit (DCS, unpublished data).

The detection of chorus frogs at two of the site occupancy survey sites demonstrates that chorus frogs are not completely absent from the western portion of the area. The pronounced decline in site occupancy rate from $58 \%$ in 1990 to only $12 \%$ in 2007 suggests chorus frogs are considerably less common across this area.

Localized declines in the Western Chorus Frog are not unusual. Daigle (1997) found that Western Chorus Frogs were absent southeast of Montreal but still widespread along the Ottawa River west of Hull, in Québec. Similarly, chorus frogs have declined in northern New York, but increased in west-central areas of the state (Gibbs et al. 2005). The recent phylogenetic analysis based on mitochondrial DNA suggesting that chorus frogs in eastern Ontario and adjacent Québec and northern New York should be assigned to the Boreal Chorus Frog rather than the Western Chorus Frog (Lemmon et al. 2007) offers another potential insight into some of the observed declines. If additional research supports this finding, then it would have been the Boreal Chorus Frog that declined in northern New York and the Western Chorus Frog that increased in distribution in west-central New York (Gibbs et al. 2005). It remains unclear why the "eastern" Boreal Chorus Frog may be more prone to decline and this should be a focus of future research.

\section{Acknowledgments}

We are indebted to Fred Schueler of the Bishops Mills Natural History Centre for first drawing our attention to the issue of chorus frog declines in eastern Ontario and for organizing the First Annual International Conference on Northeastern Pseudacris triseriata in March 2001. We are also grateful to Mike Oldham of the Natural Heritage Information Centre of the Ontario Ministry of Natural Resources for providing us with data from the Ontario Herpetofaunal Atlas. The manuscript benefited from comments from Francis Cook and three anonymous reviewers.

TABLE 2. Calling results from auditory surveys in Stormont, Dundas and Glengarry County from sites with Western Chorus Frogs in April 1990. Results by species indicate the number of sites with that species detected. Western Chorus Frog (Pseudacris triseriata), Spring Peeper (P. crucifer), Wood Frog (Lithobates sylvaticus), Northern Leopard Frog (L. pipiens), American Toad (Anaxyrus americanus), Gray Treefrog (Hyla versicolor).

\begin{tabular}{|c|c|c|c|c|c|c|c|}
\hline \multirow[b]{2}{*}{ Year } & \multirow[b]{2}{*}{$\begin{array}{l}\text { Number } \\
\text { of sites }\end{array}$} & \multicolumn{6}{|c|}{ Species } \\
\hline & & $\begin{array}{c}\text { Western } \\
\text { Chorus Frog }\end{array}$ & $\begin{array}{l}\text { Spring } \\
\text { Peeper }\end{array}$ & $\begin{array}{l}\text { Wood } \\
\text { Frog }\end{array}$ & $\begin{array}{c}\text { Northern } \\
\text { Leopard Frog }\end{array}$ & $\begin{array}{c}\text { American } \\
\text { Toad }\end{array}$ & $\begin{array}{c}\text { Gray } \\
\text { Treefrog }\end{array}$ \\
\hline 1990 & 18 & 18 & 18 & 0 & 12 & 15 & 17 \\
\hline 2001 & 17 & 0 & 17 & 13 & 9 & 8 & 0 \\
\hline 2007 & 18 & 1 & 4 & 7 & 2 & 0 & 0 \\
\hline
\end{tabular}


Documents Cited (marked * in text)

COSEWIC. 2008. COSEWIC assessment and update status report on the Western Chorus Frog Pseudacris triseriata Carolinian population and Great Lakes/St. Lawrence Canadian Shield population in Canada. Committee on the Status of Endangered Wildlife in Canada. Ottawa. vii +47 pages.

Oldham, M. J., and W. F. Weller. 2000. Ontario Herpetofaunal Atlas. Natural Heritage Information Centre, Ontario Ministry of Natural Resources. http://nhic.mnr.gov.on.ca/ herps/ohs.html (updated 09-11-2002).

\section{Literature Cited}

Austin, J. D., S. C. Lougheed, L. Neidrauer, A. C. Chek, and P. T. Boag. 2002. Cryptic lineages in a small frog: the post-glacial history of the spring peeper, Pseudacris crucifer (Anura: Hylidae). Molecular Phylogenetics and Evolution 25: 316-329.

Bleakney, S. 1959. Postglacial dispersal of the western chorus frog in eastern Canada. Canadian Field-Naturalist 73: 197-205.

Conant, R., and J. T. Collins. 1998. Peterson Field Guide to Reptiles and Amphibians of Eastern and Central North America. Third edition, expanded. Houghton-Mifflin Company, Boston.

Crewe, T. L., S. T. A. Timmermans, and K. E. Jones. 2006. The Marsh Monitoring Program 1995 to 2004: a decade of marsh monitoring in the Great Lakes region. Bird Studies Canada and Environment Canada. 28 pages.
Daigle, C. 1997. Distribution and abundance of the Chorus Frog, Pseudacris triseriata, in Québec. Pages 73-77 in Amphibians in Decline: Canadian studies of a global problem. Edited by D. M. Green. Herpetological Conservation, Volume 1. Society for the Study of Amphibians and Reptiles, St. Louis, Missouri.

Desroches, J.-F., and D. Rodrigue. 2004. Amphibians et Reptiles du Québec et des Maritimes. Editions Michel Quintin, Waterloo, Québec. 288 pages.

Gibbs, J. P., K. K. Whiteleather, and F. W. Schueler. 2005. Changes in frog and toad populations over 30 years in New York state. Ecological Applications 15: 1148-1157.

Hecnar, S. J., and R. T. M'Closkey. 1996. Regional dynamics and the status of amphibians. Ecology 77: 2091-2097.

Lemmon, E. M., A. R. Lemmon, J. T. Collins, J. A. LeeYaw, and D. C. Cannatella. 2007. Phylogeny-based delimitation of species boundaries and contact zones in the trilling chorus frogs (Pseudacris). Molecular Phylogenetics and Evolution 44: 1068-1082.

Weeber, R. C., and M. Vallinanatos. Editors. 2000. The Marsh Monitoring Program 1995-1999: Monitoring Great Lakes wetlands and their amphibian and bird inhabitants. Bird Studies Canada in cooperation with Environment Canada and the U.S. Environmental Protection Agency. 47 pages.

Received 27 March 2008

Accepted 6 May 2009 